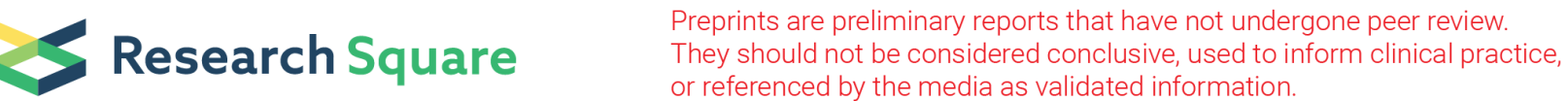

\section{Impact of the "Thinking while Moving in English" intervention on primary school children's physical activity and academic outcomes: A cluster randomized controlled trial}

\section{Myrto F Mavilidi}

The University of Newcastle School of Education

David R Lubans

The University of Newcastle School of Education

Andrew Miller

The University of Newcastle School of Education

Narelle Eather

The University of Newcastle School of Education

Philip J Morgan

The University of Newcastle School of Education

Chris Lonsdale

Australian Catholic University

\section{Michael Noetel}

Australian Catholic University

\section{Frini Karayanidis}

The University of Newcastle Faculty of Science

\section{Kylie Shaw}

The University of Newcastle School of Education

Nicholas Riley ( $\square$ nicholas.riley@newcastle.edu.au )

The University of Newcastle School of Education

\section{Research}

Keywords: physical activity, physically active lessons, on-task behavior, literacy, primary school children

Posted Date: March 27th, 2020

DOI: https://doi.org/10.21203/rs.3.rs-18509/v1

License: (c) (1) This work is licensed under a Creative Commons Attribution 4.0 International License. 
Version of Record: A version of this preprint was published at International Journal of Educational

Research on January 1st, 2020. See the published version at https://doi.org/10.1016/j.ijer.2020.101592. 


\section{Abstract}

Background: The majority of children internationally are not sufficiently active. Integrating physical activity into academic lesson time may not only help increase children's activity levels but also improve learning. The aim of this study was to assess the impact of a classroom-based physical activity intervention on primary school students' physical activity levels and academic outcomes (i.e., on-task behavior, literacy and executive function skills).

Methods: This cluster randomized controlled trial included students $(\mathrm{N}=283)$ from nine primary schools located in New South Wales, Australia. Schools were allocated to a control ( $n=5$ schools) or Thinking while Moving in English (TWM-E) ( $n=4$ schools) conditions. Teachers received professional learning (i.e. one day workshop), resources (e.g. drill ladders, lettered bean bags), and mentoring from the research team. Teachers in the TWM-E condition delivered three 40-min physically active English lessons per week for six weeks, whereas the control condition continued with the usual lessons. For both conditions, assessments occurred at baseline and post-test (six weeks). Children wore accelerometers on their wrists (Axivity) for one week during school time to measure their intensity of physical activity intensity (primary outcome). On-task behavior was assessed using a momentary time sampling procedure and expressed as a percentage of lesson time. Standardized tests were used to assess literacy skills (i.e., spelling, grammar and punctuation) and executive functioning (i.e, inhibition and task shifting).

Results: No significant group differences were observed for physical activity outcomes, spelling or executive functions. Compared to the control group, the TWM-E group displayed improved on-task behavior (adjusted mean difference $=18.1 \%$ of lesson time, $95 \% \mathrm{Cl}$ [10.12 to 26.02], $\mathrm{p}<.001, \mathrm{~d}=0.53$ ), and improved grammar and punctuation scores (adjusted mean difference $=3.0,95 \% \mathrm{Cl}[0.7$ to 5.4$], \mathrm{p}=$ $0.018, d=0.16)$.

Conclusions: Despite minimal effect on overall physical activity levels, active lessons have important benefits for students' on-task behavior and literacy.

\section{Introduction}

A wealth of studies support the benefits of physical activity for children's psychological and mental health, and educational outcomes such as school engagement, cognition, metacognition, and academic achievement ${ }^{1-4}$. A recent systematic review suggested that the time, type, context and complexity of physical activity may trigger a variety of mechanisms that mediate its relationship with cognitive function 56 . Neurobiological (e.g., enhanced release of brain-derived neurotrophic factor and increased grey matter volume), psychosocial (e.g., physical self-perceptions, mood and emotions) and behavioral (e.g., sleep volume and quality, self-regulations skills) mechanisms may explain the positive effects of physical activity on young people's academic outcomes ${ }^{5}$.

Moreover, there are quantitative and qualitative aspects of physical activity that may moderate the effect of physical activity interventions. Several reviews and high quality studies have revealed that 
participation in aerobic physical activity can improve executive functions in specific populations (e.g., low-active, overweight and obese children) ${ }^{78}$. Concomittantly, the qualitative characteristics of physical activity (e.g., type of exercise including task novelty, cognitive complexity, mental strategies activated, movement coordination) may act to increase brain stimulation ${ }^{9-11}$. For instance, preliminary evidence shows positive effects of cognitively engaging physical activity for boosting cognitive functioning ${ }^{12}$. Executive functions are especially fundamental for success in school, and every day aspects of work and life ${ }^{11}$. Core executive functions include self-regulatory cognitive operations, such as inhibition (maintaining focus), working memory (retaining and manipulating information), and cognitive flexibility (multi-tasking) ${ }^{11}$. Despite the well-established health benefits of physical activity, declining levels in children globally are alarming ${ }^{13} 14$.

Outside of physical education, sport, recess, and lunch breaks, additional opportunities for physical activity during the school day can include: i) non-curriculum focused classroom breaks, or short bouts of physical activity performed as a break from academic instruction time (also referred to as energiser breaks or activity bursts ${ }^{15}$ ), and ii) curriculum-focused physical activity. The latter include curriculumfocused physical activity breaks that contain short bouts of physical activity that include curriculum content ${ }^{16}$ (e.g., activity breaks combined with mathematics ${ }^{17}$, and physically active academic lessons that involve the integration of physical activity throughout academic lessons in key learning areas ${ }^{18}$ (e.g., active mathematics lessons ${ }^{19}$ ). Curriculum-focused active breaks and active lessons differ in terms of relevance and purpose of the task. Active breaks typically include physical activity of short duration (e.g., up to $10 \mathrm{~min}$ ) before or between academic content. Alternatively, in physically active lessons, physical activity is integrated into learning activities (typically lasting the duration of lessons; e.g., $45 \mathrm{~min}$ ). High degrees of body engagement during the learning process may help enhance learning and information retention ${ }^{20} 21$. The advantage of the integrated approach is that information can be processed simultaneously in different sub-systems, and hence, release working memory resources ${ }^{22}$.

Growing evidence affirms the positive effects of physically active lessons on children's educational outcomes ${ }^{162324}$. Results from a recent meta-analysis suggest that participation in physical activity appears to have a positive effect on students' engagement in the classroom, often reflected in improvements in 'time on-task' and concentration $(E S=0.77)^{3}$. Student engagement, often referred as 'on-task behavior' and 'time-on-task', is a prerequisite for academic success and for promoting learning by minimising classroom disruptions such as fidgeting or inattention (i.e., being "off-task" ${ }^{25-27}$ ). For example, physically active lessons have showed a $72 \%$ improvement on children's on task behavior. Also, after 2 years of implementation of three physically active lessons per week in second and third-grade classes from 12 elementary schools (e.g., jumps to solve multiplication questions), greater learning benefits were revealed in mathematics and spelling 28 .

Of note, the Programme for International Student Assessment has reported declining literacy scores across schooling years in several countries including Australia ${ }^{29}$. In general, about one quarter of 
Australian students achieve literacy scores at or below the minimum standards ${ }^{30} 31$. In response to the increased national focus on improving literacy skills, there has been a recent emphasis on improving instruction in primary school English lessons. Considering that one-fifth of the working-age population has low literacy levels ${ }^{32}$, enhancing these levels by one skill level may lead to increased likelihood of employment of $2.4-4.3 \%$ and an increase in wages of $10 \%{ }^{33}$.

Integrating physical activity in the English content may have promising physical and academic benefits by improving the learning experience. Innovative strategies are needed in the design and delivery of literacy programs, potentially reinvigorating English lessons by enhancing children's on-task behavior, motivation, and learning outcomes. Furthermore, integrating physical activity in English lessons could address the lack of time available or devoted to physical activity during the school day, especially given that time is consistently reported as an implementation barrier by teachers ${ }^{34}$. The increased foucs on physical activity has the potential to simultaneously bring about benefits both for children's physical wellbeing and their literacy scores.

We recently conducted a feasibility trial that was delivered by research staff in a single school for four weeks, and showed that the Thinking While Moving in English (TWM-E) program shows promise of improved children's on-task behavior and spelling scores ${ }^{35}$. The current efficacy trial was informed by that feasibility trial, but instead the research team trained classroom teachers to deliver the intervention after receiving professional learning. The primary objective of this cluster randomized controlled trial was to determine the effect of the TWM-E intervention on children's physical activity levels. Secondary objectives were to examine whether the TWM-E intervention improves on-task behavior, literacy skills (spelling, grammar and punctuation), and executive functioning (inhibition and task shifting).

\section{Methods}

\section{Study design}

The TWM-E cluster randomized controlled trial (RCT) was registered with the Australian and New Zealand Clinical Trials Registry (ACTRN12618001008213). Government schools were randomly selected within a 60-km radius from the University of Newcastle (e.g., Hunter, Central Coast, Newcastle regions). Written consent forms were received from school principals, teachers, and parents. Data collection occurred between April and September 2018. The design, implementation and reporting of the TWM-E study complied with the Consolidated Standards of Reporting Trials guidelines for clustered RCTs ${ }^{36}$. Detailed study methods are reported elsewhere ${ }^{37}$.

\section{Randomisation}

Schools were the unit of randomization. After receiving written consent, participating schools were matched by size and demographic characteristics based on the schools' Index of Community Socio- 
educational Advantage ${ }^{38}$, using a measure of relative advantage/disadvantage based on geographic area in Australia. Schools were randomized into experimental and waitlist control conditions after the baseline assessments using a computer-based algorithm by an independent researcher.

\section{Participants}

A total of 283 Grade 3 and 4 primary school students (Mage $=9.81, S D=0.68)$ and their teachers $(N=12)$ who were willing to deliver physically active lessons, were recruited from 9 primary schools (each school contributed one class - apart from one control and one intervention schools which had two classes). Ethics approval was obtained from the University of Newcastle, New South Wales (NSW), Australia (No: $\mathrm{H}-2017-0240$ ) and the NSW Department of Education (SERAP No: 2017368). The flow diagram of participants is portrayed in Fig. 1.

\section{Power Calculation}

Power analysis using procedures appropriate for a RCT study design ${ }^{39} 40$ were conducted to determine the sample size required to detect changes in the primary outcome of accelerometer-determined physical activity. Calculations assumed baseline to post-test correlation scores of $r=0.30$ and were based on $80 \%$ power and alpha level 0.05 . Based on the reported physical activity effects (i.e., SD change $=200$ counts per minute) after six weeks of the "Thinking While Moving in Maths" study (aka EASY Minds) pilot study and an intra-class correlation coefficient (ICC $=0.15)$, a study sample of $N=200$ with 8 clusters (i.e., schools) of 25 students would provide adequate power to detect a between group difference of 200 counts per minute across the school day ${ }^{19} 40$. We initially intended to include Actigraph accelerometers in the study, but due to lack of access to these, we used Axivity instead. Hence, the counts per minute power calculation was not relevant.

\section{Intervention}

The TWM-E program supported classroom teachers to adapt their English lessons to include movementbased learning components and to deliver these lessons over a 6-week period $(3 \times 40$ min lessons per week). The recommended lesson content was generated from the NSW K-6 English syllabus ${ }^{41}$. Participating teachers received a 1-day professional learning workshop, as well as equipment and resources for the activity components in the lessons (e.g., chalk, buckets, balls, whiteboards, drill ladders, skipping ropes, lettered bean bags, and lettered flexi-domes - value $\$ 400 \mathrm{AU})$, and mentoring of the research team in the project (including 3 face-to-face school visits and observations).

The professional learning workshop provided the rationale for physical activity integration, presented the results of the feasibility trial, and offered practical examples of physical activity integration (i.e., online videos), access to English curriculum expertise and peer-supported planning sessions ${ }^{37}$. In particular, in 
the final component of the workshop, teachers created their own action plans, highlighting the timeline, examples of activities as well as potential barriers and solutions. The professional learning workshop was registered with the National Standards Education Authority (NESA) and teachers were given five professional hours towards their accreditation ${ }^{42}$. Its content was developed according to the training model of teachers' continuing professional development ${ }^{43}$.

During the intervention, classroom teachers were responsible for the planning and delivery of all movement-based lessons. They were supported through weekly emails, answering possible questions and suggesting solutions for issues arising. The research team also provided feedback and advice stemming from face-to-face observations of the active English lessons (i.e., 40 minutes). English lessons in both intervention and control groups occurred during the usual timetable slot (e.g., 9:00-11:00 am). The control group followed their usual practice (i.e., normal curricular lessons) for the duration of the study period. Schools in the wait-list control condition received the professional learning workshop at the end of the post-intervention assessments in September 2018.

\section{Measures}

Baseline assessments took place in April-June 2018 and the post-intervention assessments in September 2018. All study measures were conducted in the schools by trained research assistants who were blinded to the group allocations at baseline. The same research assistants were used for both time points (baseline and post-intervention). However, it was not possible to blind assessors to treatment allocation at follow-up as the physically active lessons occurred during regular lesson time when data collection took place. Consenting students completed the assessments under exam-like conditions following a verbal explanation from a research assistant. Demographic information (i.e., age, sex, language spoken at home) was collected via a student questionnaire at baseline.

Primary outcome: Physical activity during the school day was measured using tri-axial wrist-worn accelerometers AX3 (Axivity, York, UK). Wrist-worn Axivity monitors have been found to have high equivalence and agreement regarding acceleration, sedentary, light and moderate-to-vigorous intensity of physical activity in adults compared to GENEActiv and Actigraph GT9X ${ }^{44}$. Accelerometers were worn for five consecutive school days (i.e., Monday to Friday) from 9:00 am to 3:00 pm. Data were downloaded in raw format using the OmiGui Software and processed in R software (http://cran.r-project.org/) using the software package GGIR ${ }^{45}$. Non-wear time was classified within a 60 min time window if for at least two out of the three axes, the standard deviation was less than $13 \mathrm{mg}$ and the value range is less than $50 \mathrm{mg}$ 46. Data were reduced by calculating the average gravity-based acceleration units (g) per 1-s epoch, with daily time spent in moderate-to-vigorous physical activity (MVPA) determined using the sum of epochs averaging above $201 \mathrm{mg}{ }^{47}$. The average minutes spent in MVPA per day and average daily wear time were computed using data from each participant's valid days. Valid days were defined as more than five school hours on any given day ${ }^{48}$, for at least 3 days ${ }^{49}$. 
Secondary outcomes: On-task behavior during English lessons was estimated as a percentage of time using a momentary time sampling adapted by Riley and colleagues ${ }^{50}$ from the "Behaviour Observation of Students in Schools" and the "Applied Behaviour Analysis for Teachers" 51 52. On-task behavior is categorized as "active engagement", defined as the time a child is actively engaged in an academic activity such as reading, writing, or performing the designated task), or "passive engagement" such as sitting quietly, sitting quietly absorbing the information but not actively engaged in the activity. Off-task behavior is defined as behavior that is not associated with the task, and classified as off-task motor such as walking around the class, off-task verbal, such as chatting, or off-task passive such as looking around in the class ${ }^{19} 53$.

Using a random number-producing algorithm, 12 students per class ( 6 males, 6 females) were randomly selected based on the alphabetical class roll. Observations occurred at both time points (baseline and post-test) by two trained research assistants. Observations were conducted at the end of 15 -sec intervals for 30-min in the allotted English time slot (i.e., 9:00-11:00 am), with each student's behavior coded as on-task (actively engaged or passively engaged) or off-task (off-task verbal, off-task motor or off-task passive) at the time. At the end of the following 15-sec interval, the next student's behavior was coded. Observers listened to an audio file via headphones, which informed them when to observe and record by circling an appropriate code (i.e., actively engaged, passively engaged or off-task) using an observation sheet. This process was repeated until each of the six students were observed 20 times.

During the actual study period, students were aware of the presence of the research team in the class, but did not know the purpose of their visit. Observers stood at the back of the classroom in order to minimise their influence the student attentiveness. We did not establish an interrater reliability for this study. Instead, we sought to assess the maximum number of students in each class. However, our research team has previously established an intraclass correlation coefficient of 0.84 for the same on-task behavior assessments (Mavilidi et al., under review).

Literacy attainment was measured using the standardized "Progressive Achievement Test", following the Australian Council for Education Research recommendations ${ }^{54}$. Children were assessed on written spelling (30 items) and grammar and punctuation (35 items). The test was administered by the regular classroom teacher and children were given a maximum time of 30 minutes for each assessment.

Executive functioning was measured using validated tests from the National Institute of Health Toolbox for 7-17 years ${ }^{556}$ delivered on tablet devices. The flanker task examines inhibitory control ability. Participants are asked to respond whether the central arrow of a multi-arrow display is pointing left or right, using index fingers of left/right hand. The flanking arrows are either congruent (i.e., pointing in the same direction as the central arrow, $\rightarrow \rightarrow \rightarrow \rightarrow \rightarrow$ ), or incongruent (i.e., pointing in the opposite direction to the central arrow, $(\rightarrow \rightarrow \leftarrow \rightarrow \rightarrow)$. Children completed four practice and twenty test trials, with the test lasting approximately 3-5 minutes. More accurate and faster responses are produced for congruent than incongruent trials 5758 . 
The dimensional change card sort test examines set-shifting ability (i.e., the ability to switch between different sorting rules). Participants have to sort pictures according to one of two dimensions (e.g., shape and colour), and use explicit cues (the words 'shape' or 'colour') to shift between sorting rules on successive trials. Children completed three practice trials and test duration was approximately 4-6 min. Both tests were scored based on children's accuracy and reaction time. When accuracy levels were less than $80 \%$, the accuracy and reaction time were combined. For scores higher than $80 \%$, the final score was equal to the accuracy score ${ }^{59}$. Higher scores indicate better performance.

\section{Process Evaluation}

The feasibility, adherence and satisfaction of the TWM-E program was assessed through:

i. Post professional learning workshop questionnaire: Teachers responded on a 5-point Likert scale, ranging from 1 (strongly disagree) to 5 (strongly agree), regarding their perception of the skills acquired from the training, the satisfaction and quality of the training, and their confidence to deliver movement-based English lessons.

ii. Fidelity (session quality): in Weeks 2, 4, and 6 active English lessons were observed by the research team and assessed on developing English concepts ( 3 items; "Movements aided and promoted learning"), physical activity levels (3 items; "Equipment used promoted physical activity"), and students' engagement (3 items; e.g., "Students were engaged by the activities taught") using a 5point Likert scale ranging from 1 (Not at all true) to 5 (Very true).

iii. Post-program student satisfaction: students responded regarding their perceptions of physically active English lessons using a 9-item questionnaire, with a 5-point Likert scale ranging from 1 (strongly disagree) to 5 (strongly agree).

\section{Statistical Analyses}

Statistical analyses were conducted using IBM SPSS (version 24) and alpha level was set at $p<0.05$. The outcomes were analyzed using linear mixed models, which are (i) consistent with the intention-to-treat principle, (ii) robust to the biases of missing data and (iii) provide appropriate balance of Type 1 and Type 2 errors ${ }^{6061}$. Considering the hierarchical structure of the data (e.g., students nested within classes and schools), multilevel modelling analyses were used to analyse all outcomes ${ }^{62}{ }^{63}$. More specifically, the models were adjusted for the clustering at class level. In the current study, school-level clustering was negligible after accounting for clustering at the class level, also supported by previous research ${ }^{64}$. The results focus on the group-by-time effects, i.e., the interaction between Group (TWM-E, control) and Time (post-test, baseline).

\section{Overview}


A summary of the demographic characteristics is presented in Table 1. The majority of the participants were from an Australian cultural background (94.6\%) and spoke English at home (97.3\%).

Table 1

Summary of demographic characteristics.

\begin{tabular}{|llll|}
\hline Characteristics & $\begin{array}{l}\text { Control } \\
(\mathbf{n = 1 6 2})\end{array}$ & $\begin{array}{l}\text { TWM-E } \\
(\mathbf{n}=121)\end{array}$ & $\begin{array}{l}\text { Total } \\
(\mathbf{n}=\mathbf{2 8 3})\end{array}$ \\
\hline Age (years), mean (SD) & $9.80(0.68)$ & $9.81(0.68)$ & $9.81(0.68)$ \\
\hline Sex, $\mathrm{n}(\%)$ & & & \\
\hline Male & $83(51.2)$ & $63(52.1)$ & $146(51.6)$ \\
\hline Female & $79(48.8)$ & $58(47.9)$ & $137(48.4)$ \\
\hline Cultural background, $\mathrm{n}(\%)$ & & & \\
\hline Australian & $139(94.6)$ & $89(84.8)$ & $228(90.5)$ \\
\hline European & $5(3.4)$ & $1(1.0)$ & $6(2.4)$ \\
\hline Asian & $1(0.7)$ & $3(2.9)$ & $4(1.6)$ \\
\hline Other & $1(1.4)$ & $12(11.5)$ & $14(5.6)$ \\
\hline Language spoken at home, $\mathrm{n}(\%)$ & & & \\
\hline English & $145(97.3)$ & $100(95.2)$ & $245(96.5)$ \\
\hline Other & $4(2.7)$ & $5(4.8)$ & $9(3.5)$ \\
\hline Aboriginal or Torres Strait Islander, $\mathrm{n}(\%)$ & & & $29(11.6)$ \\
\hline No & $132(89.2)$ & $88(87.1)$ & $220(88.4)$ \\
\hline Yes & $16(10.8)$ & $13(12.9)$ & 29 \\
\hline
\end{tabular}

\section{Results}

\section{Primary outcome}

\section{Physical activity}

There was no group-by-time effect for moderate, moderate-to-vigorous, and vigorous intensity physical activity levels (see Table 2). 
Table 2

Summary of intervention effects on physical activity outcomes.

\begin{tabular}{|c|c|c|c|c|c|c|c|c|}
\hline \multirow[t]{2}{*}{ Outcomes } & \multirow[t]{2}{*}{ Group } & Baseline M & 6-week M & \multirow{2}{*}{$\begin{array}{l}\text { Time } \\
\mathrm{p}\end{array}$} & \multirow{2}{*}{$\begin{array}{l}\text { Adj. diff. in } \\
\text { change* }^{\star}\end{array}$} & \multirow{2}{*}{$\begin{array}{l}\text { Group- } \\
\text { by-time } \\
\text { p }\end{array}$} & \multirow{2}{*}{$\begin{array}{l}\text { Group- } \\
\text { by-time } \\
d\end{array}$} & \multirow[t]{2}{*}{ ICC } \\
\hline & & $(95 \% \mathrm{Cl})$ & $(95 \% \mathrm{Cl})$ & & & & & \\
\hline \multirow[t]{2}{*}{ MVPA } & CON & $\begin{array}{l}44.89 \\
(39.93 \text { to } \\
49.85)\end{array}$ & $\begin{array}{l}46.86 \\
(41.78 \text { to } \\
51.93)\end{array}$ & 0.543 & \multirow[t]{2}{*}{$\begin{array}{l}-0.19 \\
(-10.47 \text { to } \\
10.09)\end{array}$} & \multirow[t]{2}{*}{0.969} & \multirow[t]{2}{*}{-0.01} & \multirow[t]{2}{*}{0.03} \\
\hline & $\begin{array}{l}\text { TWM- } \\
\text { E }\end{array}$ & $\begin{array}{l}51.07 \\
(45.37 \text { to } \\
56.76)\end{array}$ & $\begin{array}{l}52.85 \\
(46.90 \text { to } \\
58.79)\end{array}$ & 0.634 & & & & \\
\hline \multirow[t]{2}{*}{$\begin{array}{l}\text { Moderate } \\
\text { PA }\end{array}$} & CON & $\begin{array}{l}34.21 \\
(30.89 \text { to } \\
37.52)\end{array}$ & $\begin{array}{l}36.20 \\
(32.81 \text { to } \\
39.60)\end{array}$ & 0.348 & \multirow[t]{2}{*}{$\begin{array}{l}-0.14(-6.86 \\
\text { to } 6.58)\end{array}$} & \multirow[t]{2}{*}{0.964} & \multirow[t]{2}{*}{-0.03} & \multirow[t]{2}{*}{0.02} \\
\hline & $\begin{array}{l}\text { TWM- } \\
\text { E }\end{array}$ & $\begin{array}{l}37.16 \\
\text { (33.36 to } \\
40.97)\end{array}$ & $\begin{array}{l}39.02 \\
(35.04 \text { to } \\
42.99)\end{array}$ & 0.450 & & & & \\
\hline \multirow[t]{2}{*}{$\begin{array}{l}\text { Vigorous } \\
\text { PA }\end{array}$} & CON & $\begin{array}{l}10.71 \\
(8.18 \text { to } \\
13.24)\end{array}$ & $\begin{array}{l}10.68 \\
(8.11 \text { to } \\
13.25)\end{array}$ & 0.987 & \multirow[t]{2}{*}{$\begin{array}{l}-0.03 \\
(-5.36 \text { to } \\
5.42)\end{array}$} & \multirow[t]{2}{*}{0.991} & \multirow[t]{2}{*}{-0.00} & \multirow[t]{2}{*}{0.03} \\
\hline & $\begin{array}{l}\text { TWM- } \\
\text { E }\end{array}$ & $\begin{array}{l}14.10 \\
(11.22 \text { to } \\
16.98)\end{array}$ & $\begin{array}{l}14.10 \\
(11.12 \text { to } \\
17.09)\end{array}$ & 0.999 & & & & \\
\hline $\begin{array}{l}\text { Note: MVP } \\
\text { intervals; C } \\
\text { mean diffe } \\
\text { for baselin }\end{array}$ & = Modera & te to vigorous & $\begin{array}{l}\text { TWM-E - } \\
\text { rrelation c }\end{array}$ & $\begin{array}{l}\text { Iafter } \\
\text { icient. }\end{array}$ & ysical activi & $\begin{array}{l}\text { tion }-\mathrm{C} \\
\text { ured in } \mathrm{n}\end{array}$ & $\begin{array}{l}\text { trol) - a } \\
\text { hutes. }\end{array}$ & $\begin{array}{l}\text { lence } \\
\text { nge = } \\
\text { usted }\end{array}$ \\
\hline
\end{tabular}


Table 3

Summary of intervention effects on academic outcomes.

\begin{tabular}{|c|c|c|c|c|c|c|c|c|}
\hline \multirow[t]{2}{*}{ Outcomes } & \multirow[t]{2}{*}{ Group } & \multicolumn{2}{|l|}{$\begin{array}{l}\text { Baseline } \\
\text { M }\end{array}$} & \multirow[t]{2}{*}{$\begin{array}{l}\text { Time } \\
\mathbf{p}\end{array}$} & \multirow{2}{*}{$\begin{array}{l}\text { Adj. diff. } \\
\text { in } \\
\text { change* }^{\text {chang }}\end{array}$} & \multirow{2}{*}{$\begin{array}{l}\text { Group- } \\
\text { by- } \\
\text { time p }\end{array}$} & \multirow{2}{*}{$\begin{array}{l}\text { Group- } \\
\text { by- } \\
\text { time d }\end{array}$} & \multirow[b]{2}{*}{ ICC } \\
\hline & & $(95 \% \mathrm{Cl})$ & $(95 \% \mathrm{Cl})$ & & & & & \\
\hline \multirow[t]{2}{*}{$\begin{array}{l}\text { On-task } \\
\text { behaviour }\end{array}$} & $\mathrm{CON}$ & $\begin{array}{l}27.74 \\
(23.96 \text { to } \\
31.52)\end{array}$ & $\begin{array}{l}28.21 \\
(24.29 \text { to } \\
32.13)\end{array}$ & 0.846 & \multirow[t]{2}{*}{$\begin{array}{l}18.07 \\
(10.12 \text { to } \\
26.02)\end{array}$} & \multirow[t]{2}{*}{$\begin{array}{l}< \\
0.001\end{array}$} & \multirow[t]{2}{*}{0.53} & \multirow[t]{2}{*}{0.25} \\
\hline & $\begin{array}{l}\text { TWM- } \\
\text { E }\end{array}$ & $\begin{array}{l}30.49 \\
(26.11 \text { to } \\
34.87)\end{array}$ & $\begin{array}{l}49.02 \\
(44.54 \text { to } \\
53.51)\end{array}$ & $<0.001$ & & & & \\
\hline \multirow[t]{2}{*}{$\begin{array}{l}\text { Actively } \\
\text { engaged }\end{array}$} & CON & $\begin{array}{l}34.75 \\
(28.34 \text { to } \\
41.15)\end{array}$ & $\begin{array}{l}24.32 \\
(17.71 \text { to } \\
30.97)\end{array}$ & 0.011 & \multirow[t]{2}{*}{$\begin{array}{l}59.92 \\
(48.48 \text { to } \\
71.37)\end{array}$} & \multirow[t]{2}{*}{$\begin{array}{l}< \\
0.001\end{array}$} & \multirow[t]{2}{*}{1.26} & \multirow[t]{2}{*}{0.62} \\
\hline & $\begin{array}{l}\text { TWM- } \\
\text { E }\end{array}$ & $\begin{array}{l}35.69 \\
(28.32 \text { to } \\
43.07)\end{array}$ & $\begin{array}{l}85.19 \\
(77.69 \text { to } \\
92.69)\end{array}$ & $\begin{array}{l}<.001 \\
0.01\end{array}$ & & & & \\
\hline \multirow[t]{2}{*}{$\begin{array}{l}\text { Passively } \\
\text { engaged }\end{array}$} & CON & $\begin{array}{l}21.12 \\
(15.07 \text { to } \\
27.17)\end{array}$ & $\begin{array}{l}31.95 \\
(25.68 \text { to } \\
38.21)\end{array}$ & 0.019 & \multirow[t]{2}{*}{$\begin{array}{l}-23.01 \\
(-35.89 \text { to } \\
-10.14)\end{array}$} & \multirow[t]{2}{*}{0.002} & \multirow[t]{2}{*}{-0.88} & \multirow[t]{2}{*}{0.28} \\
\hline & $\begin{array}{l}\text { TWM- } \\
\mathrm{E}\end{array}$ & $\begin{array}{l}24.92 \\
(17.93 \text { to } \\
31.92)\end{array}$ & $\begin{array}{l}12.10(5.56 \\
\text { to } 19.91)\end{array}$ & 0.022 & & & & \\
\hline \multirow[t]{2}{*}{$\begin{array}{l}\text { Off-task } \\
\text { behaviour }\end{array}$} & CON & $\begin{array}{l}44.61 \\
(36.77 \text { to } \\
52.46)\end{array}$ & $\begin{array}{l}43.82 \\
(35.69 \text { to } \\
51.95)\end{array}$ & 0.987 & \multirow[t]{2}{*}{$\begin{array}{l}-36.38 \\
(-53.56 \text { to } \\
-19.21)\end{array}$} & \multirow[t]{2}{*}{$<0.001$} & \multirow[t]{2}{*}{-1.09} & \multirow[t]{2}{*}{0.29} \\
\hline & $\begin{array}{l}\text { TWM- } \\
\mathrm{E}\end{array}$ & $\begin{array}{l}38.75 \\
(29.67 \text { to } \\
47.83)\end{array}$ & $\begin{array}{l}1.57(-7.38 \\
\text { to } 10.89)\end{array}$ & $\begin{array}{l}< \\
0.001\end{array}$ & & & & \\
\hline \multicolumn{9}{|c|}{ Academic achievement } \\
\hline \multirow[t]{2}{*}{ Spelling } & CON & $\begin{array}{l}17.25 \\
(13.98 \text { to } \\
20.52)\end{array}$ & $\begin{array}{l}18.00 \\
(14.73 \text { to } \\
21.27)\end{array}$ & 0.286 & \multirow[t]{2}{*}{$\begin{array}{l}0.45 \\
(-1.80 \text { to } \\
2.72)\end{array}$} & \multirow[t]{2}{*}{0.653} & \multirow[t]{2}{*}{0.02} & \multirow[t]{2}{*}{0.08} \\
\hline & $\begin{array}{l}\text { TWM- } \\
\mathrm{E}\end{array}$ & $\begin{array}{l}16.10 \\
(12.52 \text { to } \\
19.68)\end{array}$ & $\begin{array}{l}17.31(13.73 \\
\text { to } 20.89)\end{array}$ & 0.143 & & & & \\
\hline \multirow[t]{2}{*}{$\begin{array}{l}\text { Grammar } \\
\text { and } \\
\text { punctuation }\end{array}$} & CON & $\begin{array}{l}21.00 \\
(18.44 \text { to } \\
23.56)\end{array}$ & $\begin{array}{l}21.01 \\
(18.45 \text { to } \\
23.58)\end{array}$ & 0.995 & \multirow[t]{2}{*}{$\begin{array}{l}3.00 \\
(0.65 \text { to } \\
5.36)\end{array}$} & \multirow[t]{2}{*}{0.018} & 0.16 & 0.11 \\
\hline & $\begin{array}{l}\text { TWM- } \\
\text { E }\end{array}$ & $\begin{array}{l}17.57 \\
(14.75 \text { to } \\
20.40)\end{array}$ & $\begin{array}{l}20.59 \\
(17.77 \text { to } \\
23.42)\end{array}$ & 0.003 & & & & \\
\hline
\end{tabular}




\begin{tabular}{|c|c|c|c|c|c|c|c|c|}
\hline \multirow[t]{2}{*}{ Outcomes } & \multirow[t]{2}{*}{ Group } & \multicolumn{2}{|l|}{$\begin{array}{l}\text { Baseline } \\
\text { M }\end{array}$} & \multirow[t]{2}{*}{$\begin{array}{l}\text { Time } \\
\text { p }\end{array}$} & \multirow{2}{*}{$\begin{array}{l}\text { Adj. diff. } \\
\text { in } \\
\text { change* }\end{array}$} & \multirow{2}{*}{$\begin{array}{l}\text { Group- } \\
\text { by- } \\
\text { time p }\end{array}$} & \multirow{2}{*}{$\begin{array}{l}\text { Group- } \\
\text { by- } \\
\text { time d }\end{array}$} & \multirow[b]{2}{*}{ ICC } \\
\hline & & $(95 \% \mathrm{Cl})$ & $(95 \% \mathrm{Cl})$ & & & & & \\
\hline \multicolumn{9}{|c|}{ Executive function } \\
\hline \multirow[t]{2}{*}{ Flanker task } & CON & $\begin{array}{l}88.45 \\
(85.51 \text { to } \\
91.39)\end{array}$ & $\begin{array}{l}91.28 \\
(88.32 \text { to } \\
94.23)\end{array}$ & $\begin{array}{l}< \\
0.001\end{array}$ & \multirow[t]{2}{*}{$\begin{array}{l}-0.72 \\
(-2.95 \text { to } \\
1.50)\end{array}$} & \multirow[t]{2}{*}{0.522} & \multirow[t]{2}{*}{-0.03} & \multirow[t]{2}{*}{0.06} \\
\hline & $\begin{array}{l}\text { TWM- } \\
\text { E }\end{array}$ & $\begin{array}{l}89.05 \\
(85.78 \text { to } \\
92.31)\end{array}$ & $\begin{array}{l}91.16 \\
(87.88 \text { to } \\
94.43)\end{array}$ & 0.014 & & & & \\
\hline \multirow[t]{2}{*}{$\begin{array}{l}\text { Dimensional } \\
\text { card game }\end{array}$} & CON & $\begin{array}{l}89.52 \\
(86.92 \text { to } \\
92.11)\end{array}$ & $\begin{array}{l}90.77 \\
(88.17 \text { to } \\
93.38)\end{array}$ & 0.122 & \multirow[t]{2}{*}{$\begin{array}{l}-0.79 \\
(-3.23 \text { to } \\
1.65)\end{array}$} & \multirow[t]{2}{*}{0.523} & \multirow[t]{2}{*}{-0.04} & \multirow[t]{2}{*}{0.05} \\
\hline & $\begin{array}{l}\text { TWM- } \\
\text { E }\end{array}$ & $\begin{array}{l}91.65 \\
(88.73 \text { to } \\
94.57)\end{array}$ & $\begin{array}{l}92.11 \\
(89.18 \text { to } \\
95.04)\end{array}$ & 0.621 & & & & \\
\hline \multicolumn{9}{|c|}{$\begin{array}{l}\text { Note: } \mathrm{M}=\text { Mean; } \mathrm{Cl}=\text { Confidence intervals; } \mathrm{CON}=\text { Control group; * Intention-to-treat linear mixed } \\
\text { models were used; Adj. diff. in change = mean difference and } 95 \% \text { CI between TWM- } \mathrm{E}-\mathrm{CON} \text { after } 6 \\
\text { weeks (Intervention - Control) - adjusted for baseline scores; ICC = intraclass correlation coefficient. } \\
\text { The highest possible scores were: } 100 \text { for on-task behaviour and executive function, } 30 \text { for spelling } \\
\text { and } 35 \text { for grammar and punctuation. }\end{array}$} \\
\hline
\end{tabular}

\section{Secondary Outcomes}

A summary of intervention effects on academic outcomes is presented in Table 3.

Significant group-by-time effects were observed for both on-task and off-task behavior in favor of the TWM-E group. Specifically, the TWM-E group increased actively engaged behaviors, and reduced both passively engaged behaviors and off-task behaviors. Significant group-by-time effects also in favor of the TWM-E group were observed for grammar and punctuation, but not for spelling. There were no significant group-by-time effects for either executive function task, i.e., inhibitory control and set-shifting ability.

\section{Process evaluation}

i. Teachers' responses on the post-workshop questionnaire (Table 4) showed high satisfaction with the overall quality of the workshop $(M=4.6 / 5, S D=0.33)$.

ii. Researcher fidelity observations of the TWM-E practical session showed that the physically active lessons targeted developing English concepts $(M=4.67 / 5, S D=0.42)$, physical activity levels $(M=$ $4.78 / 5, S D=0.27)$, and engagement $(M=4.83 / 5, S D=0.18)$. 
iii. Students' overall ratings of the TWM-E program (Table 5) were very positive $(M=4.23 / 5, S D=0.99)$, while children reported that TWM-E lessons helped them concentrate more effectively $(M=3.89 / 5$, $S D=1.07)$, and be more active $(M=4.24 / 5, S D=1.17)$. 
Table 4

Post-workshop teacher evaluation questionnaire.

Program evaluation questionnaire

$M(S D) \quad N$

1. Overall

a. The TWM-E was enjoyable.

5

b. The TWM-E workshop improved my knowledge about physical activity integration.

c. The TWM-E workshop provided me with useful information and skills that may improve my teaching.

2. Session 1 - Introduction, academic evidence

a. Provided a strong rationale for the TWM-E program.

b. The theoretical background helped outline the importance of the program.

c. The use of video clips was really helpful.

3. Session 2 - Practical session, strategies for English concepts

a. Improved my confidence to teach physically active English lessons.

b. Provided me with new ideas to teach physically active English lessons.

4. Session 3 - Planning TWM-E lessons

a. Planning an activity with colleagues was valuable.

b. Brainstorming topics has given me ideas for the program.

5. Session 4 - Delivering and evaluation

a. Working alongside peers was a positive learning experience for me.

b. Peer evaluation was a valuable tool to acquire.

c. I now feel more confident to teach movement-based English lessons.

d. The online videos and lessons were/ will be extremely valuable.

Note: Questions 1-7 were answered on a 5-point Likert scale: 1 = Strongly Disagree, $2=$ Disagree, $3=$ Neutral, 4 = Agree, 5 = Strongly Agree. Questions 6-7 were open-ended. 
Table 5

Post-program student evaluation questionnaire.

Program evaluation questionnaire

1. TWM-E lessons are enjoyable.

2. I like TWM-E lessons that are combined with physical activity.

3. I find it easier to concentrate after being physically active.

4. My teacher enjoys teaching active English lessons.

5. I look forward to TWM-E lessons.

6. TWM-E lessons help me be more active.

7. I like learning outside the classroom.

Note: Questions 1-7 were answered on a 5-point Likert scale: $1=$ Strongly Disagree, $2=$ Disagree, $3=$ Neutral, 4 = Agree, 5 = Strongly Agree. Questions 8-10 were open-ended.

\section{Discussion}

The primary aim of study was designed to evaluate the effectiveness of physically active English lessons on primary school students' physical activity levels. We did not find any significant intervention effects for physical activity outcomes. However, significant intervention effects were seen for on-task behavior and literacy attainment (i.e., grammar and punctuation). Finally, we did not see any intervention effects on spelling, or executive function. These findings indicate that after participating in the TWM-E lessons students: (i) were more engaged during lessons, and (ii) experienced greater improvements in literacy compared to the control condition.

Contrary to our hypothesis, we did not find a significant increase in children's physical activity intensity levels. The majority of research on physically active lessons has examined moderate to vigorous intensity of physical activity ${ }^{6566}$. For instance, a previous study on active learning in children at the same age group as this study (i.e., attending 4 grade) did not find changes in minutes of moderate-to-vigorous physical activity reported via accelerometery ${ }^{65}$, but did find significant changes in number of steps. Other studies on physically active lessons have reported significant improvements in primary school children's physical activity levels as measured by steps ${ }^{35} 53$, accelerometers ${ }^{6619}$, and heart-rate monitors ${ }^{67}$. It is worth noting that, when assessing interventions involving physically active lessons on students' physical activity, we need determine if the intervention has been implemented as per protocol and that there is no displacement in physical activity when children are more active during class time.

In the present study, children who participated in the active English lessons spent more time on-task than the sedentary control group. More specifically, there was a substantial increase in children's active engagement and a corresponding decrease in off-task behavior. This is important, as on-task behavior is 
a key predictor of academic success ${ }^{68}$. Previous intervention studies using physically active lessons have also demonstrated significant improvements in primary children's on-task behavior ${ }^{196569}{ }^{9}$. This is consistent with a recent meta-analysis showing that physical activity interventions produce improvements in classroom behavior $(E S=0.77)^{3}$. In addition, Owen et al. showed that integrating physical activity to classroom lessons had no effect on school engagement $(E S=0.22,95 \% \mathrm{Cl}[-0.21$, 0.66]), whereas the activity breaks during academic lessons produced medium sized improvements in school engagement $(E S=0.55)^{4}$. This discrepancy between the present findings and Owen's conclusions may be due to the fact that we used observational measures of classroom engagement compared to only $30 \%$ of studies in Owen et al., 2016) ${ }^{4}$. Alternatively, it may be that our intervention was more explicitly focused with physical activity outcomes, compared with other physically active lessons. This would suggest that the professional learning workshop was successful in providing adequate training and support during implementation to teachers to effectively implement active lessons. This is particularly important, as many unsuccessful school-based physical activity interventions have not been implemented as intended 7071 .

Importantly, this study found significant albeit small improvements in children's literacy attainment, namely grammar and punctuation skills. A recent meta-analysis supported the effectiveness of the physical activity programs on children's learning outcomes, with effects in several academic domains (i.e., mathematics, $E S=0.21$ and reading, $E S=0.13$, in children $4-13$ years ${ }^{3}$, but no effects on languagerelated skills. In addition, a 2-year randomized controlled trial (three times per week for two years, 22 weeks per year) in second and third grade class from 12 elementary schools found improved mathematics and spelling (but not reading) scores compared to a sedentary control group 28 .

Contrary to previous research ${ }^{35} 67$, we did not find any difference on children's spelling scores. This could be due to the relatively short duration of the intervention. It is also possible that the physical activities selected by the teachers focused more on grammar and punctuation skills, or that teachers did not provide sufficient feedback on correct spelling to children after performing the physically active spelling activities.

Alternatively, standardized tests for spelling may not able to capture changes in students' progress over a short time-frame. Future research should focus on targeting activities that explicitly improve spelling skills if that is an area of concern with classroom teachers. Nevertheless, considering the short study duration, this intervention offers promising results on learning outcomes and in particular grammar and punctuation.

Lastly, no intervention effects were observed regarding children's executive functions. Currently, there is a scientific debate regarding the effects of physical activity on executive functions. In a recent review, Diamond and Ling ${ }^{11}$ stated that exercise can enhance executive function ability only when it specifically involves practice of executive functioning skills. Thus, physical activities such as martial arts or yoga that explicitly train diverse executive functions can produce more prominent cognitive benefits than treadmill 
running, or stationary biking. In contrast, Hillman and colleagues have argued that aerobic exercise that improves cardiorespiratory fitness can enhance activation in brain areas that support executive functioning and high-order thinking (e.g., motor cortex, cerebellum, basal ganglia) ${ }^{7}$ as well as executive function ability 72 .

Current evidence suggests the benefits of high intensity physical activity on fitness, and mental and cognitive health ${ }^{7374}$. Hence, it is likely that the volume and intensity of physical activity implemented in the present interventions were insufficient to improve children's physical fitness and in turn, elicit substantial neurobiological and cognitive changes. Animal studies suggest that improvements in cardiorespiratory fitness are necessary to induce neurogenesis ${ }^{75}$. Particularly, strenuous aerobic exercise (e.g., heart rate reaching $70-85 \%{ }^{76}$ or around $120 \mathrm{bpm}$ in adolescents ${ }^{77}$ and $160 \mathrm{bpm}$ in children aged 9-10 years ${ }^{978}$ ), appears to be required to improve executive functions.

Chronic interventions targeting cognitively engaging physical activity have shown improvements in children's executive function skills ${ }^{79} 80$. For instance, a study in children 7-9 years involving cognitivelyengaging physical activity breaks revealed delayed effects in cognitive (i.e., shifting) and learning (i.e., mathematics) performance after 20 weeks ${ }^{81}$. Moreover, a recent study integrated physical activity with language learning in primary school children. The intervention occurred 10-min per day, twice per week for two weeks. Although children's learning improved after the end of the intervention, no acute effects were found on attentional performance which, in fact, deteriorated ${ }^{82}$. In addition, children's self-reported level of cognitive exertion did not vary between the condition that integrated physical activity with learning and the control condition.

\section{Educational implications}

Overall, the TWM-E intervention delivered over a 6-week interval improved on-task behavior and academic performance. The program components (delivery and content) were well-received by teachers and students, showing the program's feasibility and potential sustainability for introducing movement-based English lessons in primary school students, and their potential to become part of the regular practice. Importantly, the post-program evaluation questionnaire revealed that children rated the program as very enjoyable, consistent with evidence from other studies that students consider integrating physical activity an enjoyable teaching method of several learning domains ${ }^{83-88}$. High levels of perceived competence and need satisfaction can result in increased self-efficacy (i.e., confidence in someone's ability to perform a task), and inherent motivation, and in turn, improved academic performance ${ }^{89}$. In fact, positive mood can improve academic outcomes with regard to engagement and achievement ${ }^{90} 91$, with motivated students showing higher engagement in lessons and obtaining higher grades ${ }^{92} 93$.

Study limitations

A number of limitations may have impacted the strength and breadth of outcomes. First, the duration of the intervention was only six weeks. Longer-term interventions are needed to evaluate whether observed effects are sustained and other effects may emerge. Secondly, schools and teachers consented to participating in the study and were therefore motivated to succeed. In real-word contexts, this 
instructional approach involving active English lessons might not be accepted by all teachers. Moreover, even though if this intervention was designed to increase physical activity during lesson time, it is possible that some teachers replaced time for physical education with physically active lessons. Fidelity checks confirmed that regular English lessons were substituted by physically active lessons.

In addition, although Axivity monitors have been shown to be reliable measuring physical activity in over 100,000 participants ${ }^{94}$, with primary school aged children, most research uses waist-worn Actigraph accelerometers ${ }^{19} 95$, while the one study that used Axivity Ax3 accelerometers had them mounted with tape on the waist ${ }^{96}$. It is suggested that when using Axivity accelerometers in children, a dualaccelerometer system with sensors placed on the thigh and the back should be included for greater accuracy ${ }^{97}$. However, this may not be a viable option for school-based research in young children. Wristworn Axivity monitors have been found to have high equivalence and agreement regarding acceleration, sedentary, light and moderate-to-vigorous intensity of physical activity in adults compared to wrist-straps GENEActiv and Actigraph GT9X ${ }^{44}$. Nonetheless, it is important to note the on-going debate regarding wrist-worn and waist-worn accelerometetry, with significant and substantial differences depicted in counts per minutes across all intensities ${ }^{98}$.

\section{Conclusions}

The benefits of physical activity for children's physical, social, psychological development are wellestablished. The TWM-E intervention presents a feasible and practical approach to increase engagement in primary school children, with potential physical activity benefits for combatting the declining levels of physical activity in children. Importantly, this study shows that physically active lessons can enhance children's literacy attainment, key area requiring urgent policy and practice amendments by stakeholders.

\section{References}

1. Khan NA, Hillman $\mathrm{C}, \mathrm{H}$. The relation of childhood physical activity and aerobic fitness to brain function and cognition: a review. Pediatr. Exerc. Sci. 2014;26:138-46.

2. Singh AS, Saliasi E, van den Berg V, et al. Effects of physical activity interventions on cognitive and academic performance in children and adolescents: a novel combination of a systematic review and recommendations from an expert panel. Br J Sports Med. 2019;53(10):640-47. doi: 10.1136/bjsports2017-098136

3. Álvarez-Bueno C, Pesce C, Cavero-Redondo I, et al. Academic achievement and physical activity: A meta-analysis. Pediatrics 2017;140(6):e20171498.

4. Owen KB, Parker PD, Van Zanden B, et al. Physical activity and school engagement in youth: A systematic review and meta-analysis. Educ Psych 2016;51(2):129-45.

5. Valkenborghs SR, Noetel $\mathrm{M}$, Hillman $\mathrm{CH}$, et al. The impact of physical activity on brain structure and function in youth: A systematic review. Pediatrics 2019;144(4):1-16. doi: 10.1542/peds.2018-4032 
6. Lubans DR, Richards J, Hillman $\mathrm{CH}$, et al. Physical activity for cognitive and mental health in youth: A systematic review of mechanisms. Pediatrics 2016;138(3):e20161642. doi: 10.1542/peds.2016-1642

7. Hillman $\mathrm{CH}, \mathrm{McAuley} \mathrm{E}$, Erickson $\mathrm{Kl}$, et al. On mindful and mindless physical activity and executive function: A response to Diamond and Ling (2016). Dev. Cogn. Neurosci. 2019;37:100529-29. doi: 10.1016/j.dcn.2018.01.006 [published Online First: 2018/10/12]

8. de Greeff JW, Hartman E, Mullender-Wijnsma MJ, et al. Long-term effects of physically active academic lessons on physical fitness and executive functions in primary school children. Health Educ. Res. 2016;31(2):185-94. doi: 10.1093/her/cyv102

9. Best JR. Effects of physical activity on children's executive function: Contributions of experimental research on aerobic exercise. Dev. Rev. 2010;30(4):331-51.

10. Pesce $C$. Shifting the focus from quantitative to qualitative exercise characteristics in exercise and cognition research. J Sport Exercise Psy 2012;34(6):766-86. doi: 10.1123/jsep.34.6.766

11. Diamond A, Ling DS. Conclusions about interventions, programs, and approaches for improving executive functions that appear justified and those that, despite much hype, do not. Dev. Cogn. Neurosci. 2016;18:34-48. doi: https://doi.org/10.1016/j.den.2015.11.005

12. Vazou $S$, Pesce $C$, Lakes $K$, et al. More than one road leads to Rome: a narrative review and metaanalysis of physical activity intervention effects on cognition in youth. Int. J. Sport Exerc. Psychol. 2016:1-26.

13. Hallal PC, Andersen LB, Bull FC, et al. Global physical activity levels: surveillance progress, pitfalls and prospects. The Lancet 2012;380:247-57.

14. Griffiths LJ, Cortina-Borja M, Sera F, et al. How active are our children? Findings from the Millennium Cohort Study. BMJ Open 2013;3(8):e002893. doi: 10.1136/bmjopen-2013-002893

15. Katz DL, Cushman D, Reynolds J, et al. Putting physical activity where it fits in the school day: preliminary results of the $A B C$ (Activity Bursts in the Classroom) for fitness program. Prev Chronic Dis 2010;7(4):1-10.

16. Watson A, Timperio A, Brown $\mathrm{H}$, et al. Effect of classroom-based physical activity interventions on academic and physical activity outcomes: a systematic review and meta-analysis. Int J Behav Nutr Phys Act 2017;14(1):114. doi: 10.1186/s12966-017-0569-9

17. Mavilidi MF, Drew R, Morgan PJ, et al. Effects of different types of classroom physical activity breaks on children's on-task behaviour, academic achievement and cognition. Acta Paediatr. 2020;109(1):158-65.

18. Mavilidi MF, Okely AD, Chander P, et al. Effects of integrated physical exercises and gestures on preschool children's foreign language vocabulary learning. Educ. Psychol. Rev. 2015;27(3):413-26.

19. Riley N, Lubans DR, Holmes K, et al. Findings from the EASY Minds cluster randomized controlled trial: evaluation of a physical activity integration program for mathematics in primary schools. $J$ Phys Act Health 2016;13:198-206. doi: http://dx.doi.org/10.1123/jpah.2015-0046

20. Thompson BN, Goldstein TR. Children learn from both embodied and passive pretense: A replication and extension. Child Dev. in press doi: 10.1111/cdev.13309 
21. Mavilidi MF, Ruiter M, Schmidt M, et al. A narrative review of school-based physical activity for enhancing cognition and learning: The importance of relevancy and integration. Front Psychol 2018;9:1-17. doi: 10.3389/fpsyg.2018.02079

22. Mavilidi $M$, Ouwehand $K$, Okely $A D$, et al. Embodying learning through physical activity and gestures in preschool children. In: S. Tindall-Ford SA, \& J. Sweller, ed. Advances in Cognitive Load Theory: Rethinking Teaching. London: Routledge 2020:103-18.

23. Norris $E$, van Steen T, Direito A, et al. Physically active lessons in schools and their impact on physical activity, educational, health and cognition outcomes: a systematic review and metaanalysis. Br J Sports Med. in press:bjsports-2018-100502. doi: 10.1136/bjsports-2018-100502

24. Daly-Smith AJ, Zwolinsky S, McKenna J, et al. Systematic review of acute physically active learning and classroom movement breaks on children's physical activity, cognition, academic performance and classroom behaviour: understanding critical design features. BMJ Open Sport Exerc. Med. 2018;4(1):e000341. doi: 10.1136/bmjsem-2018-000341

25. Greenwood CR, Horton, B.T., Ytlley CA. Academic engagement:current perspectives in research and practice. School Psych Rev. 2002;31(3):328-49.

26. Fredricks JA, Blumenfeld PC, Paris AH. School engagement: Potential of the concept, state of the evidence. Rev. Educ. Res. 2004;74(1):59-109. doi: 10.3102/00346543074001059

27. Donnelly JE, Lambourne K. Classroom-based physical activity, cognition, and academic achievement. Prev Med 2011;52(Suppl 1):S36-S42. doi: 10.1016/j.ypmed.2011.01.021

28. Mullender-Wijnsma MJ, Hartman E, de Greeff JW, et al. Physically active math and language lessons improve academic achievement: A cluster randomized controlled trial. Pediatrics 2016;137(3) doi: 10.1542/peds.2015-2743

29. OECD. PISA 2018 Results, Combined executive summaries. Volume I, II, \& III Paris, France: OECD; 2019 [Available from: https://login.ezproxy.newcastle.edu.au/login? url=https://www.oecd.org/pisa/Combined_Executive_Summaries_PISA_2018.pdf.

30. Hempenstall K. Read about it: Scientific evidence for effective teaching of reading. Research Report 11. Sydney, Australia: The Centre for Independent Studies 2016.

31. NSW Board of Studies Teaching \& Educational Standards. Parents' guide to the NSW primary syllabuses (incorporating the Australian curriculum). Helping parents to understand their child's progress through primary school. 2014 [Available from:

https://educationstandards.nsw.edu.au/wps/wcm/connect/f316419e-11c4-4d9a-840f0d686d1e3668/parents-guide-2015.pdf?MOD=AJPERES\&CVID $=$.

32. OECD. Building skills for all in Australia. Policy insights from the survey of adult skills. 2017 [Available from: https://www-oecd-org.ezproxy.newcastle.edu.au/australia/building-skills-for-all-inaustralia-9789264281110-en.htm.

33. Shomos A, Forbes M. Literacy and numeracy skills and labour market outcomes in Australia.: Australian Government Productivity Commission 2014. 
34. Naylor PJ, Nettlefold L, Race D, et al. Implementation of school based physical activity interventions: A systematic review. Prev. Med. 2015;72:95-115. doi: http://dx.doi.org/10.1016/j.ypmed.2014.12.034

35. Mavilidi M, Lubans D, Eather N, et al. Preliminary efficacy and feasibility of "Thinking While Moving in English": A program with physical activity integrated into primary school English lessons. Children 2018;5(8):109.

36. Campbell MK, Elbourne DR, Altman DG. CONSORT statement: extension to cluster randomised trials. BMJ 2004;328(7441):702-08.

37. Mavilidi MF, Lubans DR, Morgan PJ, et al. Integrating physical activity into the primary school curriculum: rationale and study protocol for the "Thinking while Moving in English" cluster randomized controlled trial. BMC Public Health 2019;19(1):1-12. doi: 10.1186/s12889-019-6635-2

38. Australian Bureau of Statistics. Socio-economic indexes for areas: Census of population and housing: Canberra, Australia; 2016 [Available from: https://www.abs.gov.au/ausstats/abs@.nsf/mf/2033.0.55.001.

39. Donner A, Klar N. Design and analysis of cluster randomization trials in health research. London: Arnold Publishing, Hodder Headline Group 2000.

40. Riley N, Lubans DR, Holmes K, et al. Rationale and study protocol of the EASY Minds (Encouraging Activity to Stimulate Young Minds) program: Cluster randomized controlled trial of a primary schoolbased physical activity integration program for mathematics. BMC Public Health 2014;14(819):10.1186/471-2458-14-816.

41. NSW Education Standards Authority. English K-10 syllabus 2012 [Available from: https://educationstandards.nsw.edu.au/wps/portal/nesa/k-10/learning-areas/english-year10/english-k-10.

42. NSW Education Standards Authority. Teacher accreditation. Providing high quality professional development for teachers. 2017 [Available from: https://educationstandards.nsw.edu.au/wps/portal/nesa/teacher-accreditation/how-accreditationworks/providing-professional-development.

43. Kennedy A. Models of continuing professional development: a framework for analysis. J Serv Educ 2005;31(2):235-50. doi: 10.1080/13674580500200277

44. Rowlands AV, Mirkes EM, Yates TE, et al. Accelerometer-assessed physical activity in epidemiology: Are monitors equivalent? Med. Sci. Sports Exerc. 2017;50(2):257-65.

45. van Hees VT, Gorzelniak L, Dean León EC, et al. Separating movement and gravity components in an acceleration signal and implications for the assessment of human daily physical activity. PLOS ONE 2013;8(4):e61691. doi: 10.1371/journal.pone.0061691

46. Sabia S, van Hees VT, Shipley MJ, et al. Association between questionnaire- and accelerometerassessed physical activity: The role of sociodemographic factors. Am J Epidemiol 2014;179(6):78190. doi: $10.1093 /$ aje/kwt330

47. Hildebrand $\mathrm{M}$, Van Hees VT, Hansen $\mathrm{BH}$, et al. Age group comparability of raw accelerometer output from wrist- and hip-worn monitors. Med. Sci. Sports Exerc. 2014;46(9):1816-24. doi: 
10.1249/mss.0000000000000289

48. Barnett LM, Ridgers ND, Salmon J. Associations between young children's perceived and actual ball skill competence and physical activity. J Sci Med Sport 2015;18(2):167-71. doi:

http://dx.doi.org/10.1016/j.jsams.2014.03.001

49. Cain KL, Sallis JF, Conway TL, et al. Using accelerometers in youth physical activity studies: A review of methods. J Phys Act Health 2013;10(3):437. doi: 10.1123/jpah.10.3.437

50. Riley N, Morgan PJ, Lubans DR. Outcomes and process evaluation of a program integrating physical activity into the primary school mathematics curriculum: The EASY Minds pilot randomized controlled trial J Sci Med Sport 2015 doi: http://dx.doi.org/10.1016/j.jsams.2012.11.217

51. Alberto P, Troutman A. Applied Behaviour Analysis for Teachers. 6 ed: Pearson Education 2003.

52. Shapiro ES, Cole CL. Behaviour change in the classroom: self management interventions. New York: Guildford press 1994.

53. Mahar MT, Murphy SK, Rowe DA, et al. Effects of a classroom-based program on physical activity and on-task behaviour. Med. Sci. Sports Exerc. 2006;38:2086-94.

54. Stephanou A, Anderson P, Urbach D. PAT-R Progressive Achievement Tests in Reading: comprehension, vocabulary and spelling. Camberwell, Victoria: Australian Council for Educational Research (ACER) Press 2008.

55. Health Measures. 2018 NIH Toolbox [Available from: http://www.healthmeasures.net/exploremeasurement-systems/nih-toolbox.

56. Lockhart KL, Keil FC. II. The proper realms of medicines and their alternatives: What count as cures? . Monogr Soc Res Child Dev 2018;83(2):33-62. doi: doi:10.1111/mono.12362

57. Hillman $\mathrm{CH}$, Snook EM, Jerome GJ. Acute cardiovascular exercise and executive control function. Int J Psychophysiol 2003;48(3):307-15.

58. Eriksen CW, Schultz DW. Information processing in visual search: A continuous flow conception and experimental results. Percept Psychophys 1979;25(4):249-63. doi: 10.3758/bf03198804

59. Slotkin J, Nowinski C, Hays R, et al. NIH Toolbox. Scoring and interpretation: National Institutes of Health and Northwestern University; 2012 [Available from:

https://www.epicrehab.com/epic/documents/crc/crc-201307-nih-toolbox-scoring-and-interpretationmanual\%209-27-12.pdf.

60. Mallinckrodt $\mathrm{CH}$, Watkin JG, Molenberghs G, et al. Choice of the primary analysis in longitudinal clinical trials. Pharm Stat. 2004;3(3):161-69. doi: 10.1002/pst.124

61. Krull JL, MacKinnon DP. Multilevel modeling of individual and group level mediated effects. Multivariate Behav Res 2001;36:249-77.

62. Raudenbush SW, Bryk AS. Hierarchical linear models: Applications and data analysis methods: Sage 2002.

63. Hox J. Multilevel modeling: When and why. Berlin, Heidelberg: Springer Berlin Heidelberg 1998:14754. 
64. Lonsdale C, Lester A, Owen KB, et al. An internet-supported school physical activity intervention in low socioeconomic status communities: results from the Activity and Motivation in Physical Education (AMPED) cluster randomised controlled trial. Br J Sports Med. 2019;53(6):341-47. doi: 10.1136/bjsports-2017-097904

65. Bartholomew JB, Golaszewski NM, Jowers E, et al. Active learning improves on-task behaviors in 4th grade children. Active learning improves on-task behaviors in 4th grade children 2018;111:49-54. doi: https://doi.org/10.1016/j.ypmed.2018.02.023

66. Szabo-Reed AN, Willis EA, Lee J, et al. Impact of three years of classroom physical activity bouts on time-on-task behavior. Med Sci Sports Exerc 2017;49(11):2343-50. doi:

10.1249/MSS.0000000000001346

67. Mullender-Wijnsma MJ, Hartman E, de Greeff JW, et al. Improving academic performance of schoolage children by physical activity in the classroom: 1-year program evaluation. J. Sch. Health 2015;85(6):365-71. doi: 10.1111/josh.12259

68. de Greeff JW, Bosker RJ, Oosterlaan J, et al. Effects of physical activity on executive functions, attention and academic performance in preadolescent children: a meta-analysis. J Sci Med Sport 2017 doi: https://doi.org/10.1016/j.jsams.2017.09.595

69. Grieco LA, Jowers EM, Errisuriz VL, et al. Physically active vs. sedentary academic lessons: A dose response study for elementary student time on task. Prev. Med. 2016;89:98-103. doi: https://doi.org/10.1016/j.ypmed.2016.05.021

70. Metcalf B, Henley W, Wilkin T. Effectiveness of intervention on physical activity of children: Aystematic review and meta-analysis of controlled trials with objectively measured outcomes. $\mathrm{Br}$ Med J 2012;345

71. Borde R, Smith JS, Sutherland R, et al. Methodological considerations and impact of school-based interventions on objectively measured physical activity in adolescents: A systematic review and meta-analysis. Obes Rev 2017;18(4):476-90. doi: 10.1111/obr.12517

72. Colcombe S, Kramer AF. Fitness effects on the cognitive function of older adults: A meta-analytic study. Psychol. Sci. 2003;14(2):125-30. doi: 10.1111/1467-9280.t01-1-01430

73. Donnelly JE, Hillman $\mathrm{CH}$, Castelli D, et al. Physical activity, fitness, cognitive function, and academic achievement in children: a systematic review. Med. Sci. Sports Exerc. 2016;48(6):1197-222.

74. Ruiz JR, Ortega FB, Castillo R, et al. Physical activity, fitness, weight status, and cognitive performance in adolescents. J. Pediatr. 2010;157(6):917-22. doi:

https://doi.org/10.1016/j.jpeds.2010.06.026

75. Gomez-Pinilla F, Hillman C. The influence of exercise on cognitive capabilities. Compr. Physiol. 2013;3:403-28. doi: 10.1002/cphy.c110063

76. Chang YK, Labban JD, Gapin JI, et al. The effects of acute exercise on cognitive performance: a meta-analysis. Brain Res 2012;1453:87-101. doi: 10.1016/j.brainres.2012.02.068 [published Online First: 2012/04/07] 
77. Budde H, Voelcker-Rehage C, Pietraßyk-Kendziorra S, et al. Acute coordinative exercise improves attentional performance in adolescents. Neurosci. Lett 2008;441(2):219-23.

78. Best JR. Exergaming immediately enhances children's executive function. Dev Psychol 2012;48(5):1501-10. doi: 10.1037/a0026648 [published Online First: 2011/12/14]

79. Schmidt M, Jäger K, Egger F, et al. Cognitively engaging chronic physical activity, but not aerobic exercise, affects executive functions in primary school children: A group-randomized controlled trial. J Sport Exerc Psychol 2015;37(6):575-91. doi: 10.1123/jsep.2015-0069

80. Crova C, Struzzolino I, Marchetti R, et al. Cognitively challenging physical activity benefits executive function in overweight children. J Sport Sci 2014;32(3):201-11. doi: 10.1080/02640414.2013.828849

81. Egger F, Benzing V, Conzelmann A, et al. Boost your brain, while having a break! The effects of longterm cognitively engaging physical activity breaks on children's executive functions and academic achievement. PloS one 2019;14(3):e0212482.

82. Schmidt M, Benzing V, Wallman-Jones A, et al. Embodied learning in the classroom: Effects on primary school children's attention and foreign language vocabulary learning. Psychol Sport Exerc. 2019;43:45-54. doi: https://doi.org/10.1016/j.psychsport.2018.12.017

83. Vazou S, Smiley-Oyen A. Moving and academic learning are not antagonistis: Acute effects on executive function and enjoyment. J Sport Exerc Psychol. 2014;36:474-85.

84. Vazou S, Skrade MA. Intervention integrating physical activity with math: math performance, perceived competence, and need satisfaction. Int. J. Sport Exerc. Psychol. 2016:1-15.

85. Mavilidi MF, Okely AD, Chandler P, et al. Immediate and delayed effects of integrating physical activity into preschool children's learning of numeracy skills. J. Exp. Child Psychol. 2018;166:502-19.

86. Mavilidi MF, Okely AD, Chandler P, et al. Infusing physical activities into the classroom: Effects on preschool children's geography learning. Mind Brain Educ. 2016;10(4):256-63.

87. Mavilidi MF, Okely AD, Chandler $P$, et al. Effects of integrating physical activities into a science lesson on preschool children's learning and enjoyment. Appl. Cogn. Psychol. 2017;31(2):281-90.

88. Toumpaniari K, Loyens S, Mavilidi M-F, et al. Preschool children's foreign language vocabulary learning by embodying words through physical activity and gesturing. Educ Psychol Rev 2015;27(3):445-56. doi: 10.1007/s10648-015-9316-4

89. Deci EL, Ryan RM. Self-determination theory: A macrotheory of human motivation, development, and health. Can. Psychol. 2008;49(3):182-85. doi: 10.1037/a0012801

90. Ahmed W, van der Werf G, Kuyper H, et al. Emotions, self-regulated learning, and achievement in mathematics: A growth curve analysis. J. Educ. Psychol. 2013;105(1):150-61. doi: $10.1037 / \mathrm{a} 0030160$

91. Pekrun R, Linnenbrink-Garcia L. Academic emotions and student engagement. In: Christenson SL, Reschly AL, Wylie C, eds. Handbook of Research on Student Engagement. Boston, MA: Springer US 2012:259-82. 
92. Robinson KA, Ranellucci J, Lee Y-k, et al. Affective profiles and academic success in a college science course. Contemp Educ Psychol. 2017;51:209-21. doi:

https://doi.org/10.1016/j.cedpsych.2017.08.004

93. Wentzel KR, Wigfield A. Academic and social motivational influences on students' academic performance. Educ. Psychol. Rev. 1998;10(2):155-75. doi: 10.1023/a:1022137619834

94. Doherty A, Jackson D, Hammerla N, et al. Large scale population assessment of physical activity using wrist worn accelerometers: The UK Biobank study. PloS one 2017;12(2):e0169649. doi: 10.1371/journal.pone.0169649

95. Donnelly JE, Greene JL, Gibson CA, et al. Physical activity and academic achievement across the curriculum (A + PAAC): rationale and design of a 3-year, cluster-randomized trial. BMC Public Health 2013;13:307. doi: 10.1186/1471-2458-13-307

96. Schneller MB, Duncan S, Schipperijn J, et al. Are children participating in a quasi-experimental education outside the classroom intervention more physically active? BMC Public Health 2017;17(1):523. doi: 10.1186/s12889-017-4430-5

97. Stewart T, Narayanan A, Hedayatrad L, et al. A dual-accelerometer system for classifying physical activity in children and adults. Med Sci Sports Exerc 2018;50(12):2595-602. doi: $10.1249 / \mathrm{mss} .0000000000001717$

98. Loprinzi PD, Smith B. Comparison between wrist-worn and waist-worn accelerometry. J Phys Act Health 2017;14(7):539. doi: 10.1123/jpah.2016-0211

\section{Declarations}

\section{Ethics approval and consent to participate}

This manuscript involves ethics approval from the University of Newcastle, New South Wales (NSW), Australia (No: H-2017-0240) and the NSW Department of Education (SERAP No: 2017368). Written consent forms were received from school principals, teachers, and parents.

\section{Consent for publication}

Not applicable

\section{Availability of data and material}

The datasets during and/or analysed during the current study available from the corresponding author on reasonable request.

\section{Competing interests}

The authors declare that they have no competing interests

\section{Funding}


Funding was received from the NSW Department of Education, School Sport Unit (G1700722)

\section{Authors' contributions}

MFM and DM analyzed and interpreted the data. NR, NE, DL, PM, KS, design the intervention. FK provided expertise on the cognitive outcomes. MFM drafted the manuscript. All authors reviewed, read and approved the final manuscript.

\section{Acknowledgements}

We would like to thank all participating schools and children involved.

\section{Abbreviations}

$\mathrm{Cl} \quad$ Confidence Intervals

CON Control

ES Effect Size

ICC Intra-class Correlation Coefficient

M Mean

MPA Moderate Physical Activity

MVPA Moderate-to-vigorous Physical Activity

NSW New South Wales

RCT Randomised Controlled Trial

SD Standard Deviation

SE Standard Error

TWM-E Thinking While Moving in English

VPA Vigorous Physical Activity

\section{Figures}




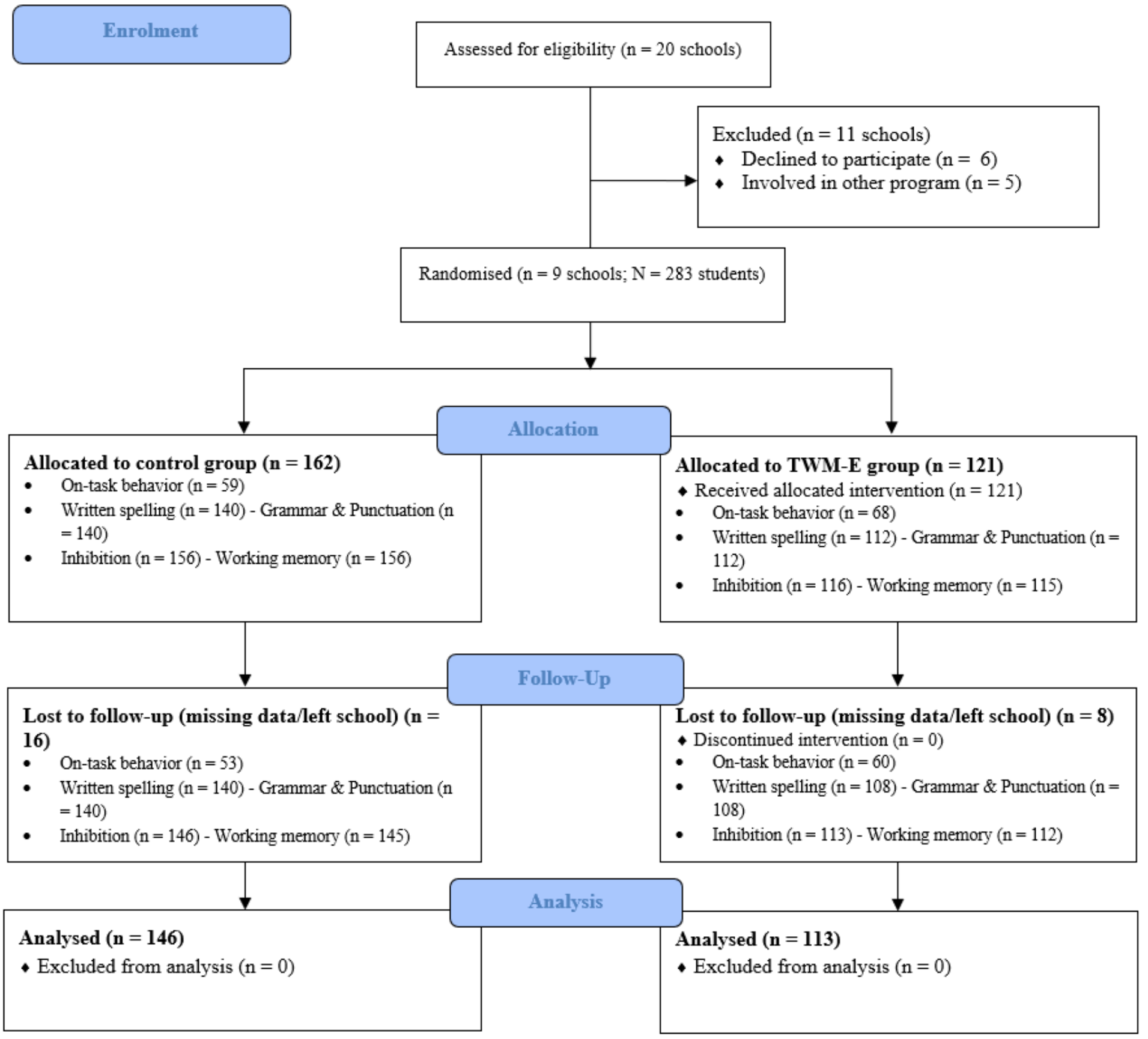

\section{Figure 2}

CONSORT flow diagram.

\section{Supplementary Files}

This is a list of supplementary files associated with this preprint. Click to download.

- TIDieRChecklistWord.docx

- TIDieRChecklistWord.docx 
- CONSORTExtensionforClusterTrials2012Checklist.docx

- CONSORTExtensionforClusterTrials2012Checklist.docx 